\title{
On the Unimpairable Resistance of the Guinea Pig to Dietary Amino Azo Dye Hepatocarcinogenesis*
}

\author{
H. H. Gosch**, J. C. Arcos and M. F. ARguS \\ Seamen's Memorial Research Laboratory, US Public Health Service Hospital, 210StateStreet, \\ New Orleans, Louisiana, 70118 (USA); and Department of Medicine (Biochemistry), Tulane \\ University School of Medicine, New Orleans
}

Received March 18, 1969

Die Resistenz des Meerschweinchens gegenüber der hepatocarcinogenen Wirkung von gefütterten Amino-Azo-Farbstoffe

Zusammenfassung. Die Resistenz des Meerschweinchens gegenüber der hepatocarcinogenen Wirkung von 3'-Methyl-4-dimethylaminoazobenzene, das mit 0,12\% insgesamt 8 Monate gefüttert wurde, wird auch durch den starken co-carcinogenen Einfluß einer Partialhepatektomie nicht gebrochen.

Summary. The resistance of the guinea pig to carcinogenesis by $3^{\prime}$-methyl-4-dimethylaminoazobenzene fed at the level of $0.12 \%$ for a total of 8 months is not overcome by the potent cocarcinogenie influence of partial hepatectomy performed at 4 weeks.

There is substantial evidence for the cocarcinogenic effect of trauma in general and partial hepatectomy in particular. GLINos and BUCHER (1949) and GLINos et al. (1951) reported the shortening of the latent period of hepatic tumors in rats in which partial hepatectomy was carried out during administration of 4-dimethylaminoazobenzene (DAB). LAws (1959) found an acceleration of 2-acetylaminofluorene-induced hepatic carcinogenesis in rats, and Holcander and BentvelzeN (1968) noted an increase of the incidence of urethan-induced hepatomas in mice by the concomitant action of partial hepatectomy. The emergence and growth of spontaneous mouse hepatomas are also hastened by partial hepatectomy (Echave Llanos, and Saffe, 1963). Moreover, partial hepatectomy was successfully used to bring to evidence the latent or marginal carcinogenicity of 2-methyl$D A B$ in the rat. This compound (often regarded as noncarcinogenic) is, in fact, not entirely devoid of activity. For example, in our Laboratory occasional tumorbearers were found in groups of 20-25 male Sprague-Dawley rats each, maintained for 13-15 months on the usual semi-synthetic diet (Arcos et al., 1961) containing $0,06 \%$ of this dye. WARWICK (1967) reported that feeding of 2-methyl$\mathrm{DAB}$ at $0.06 \%$ level in a $10 \%$ protein diet, combined with partial hepatectomy

* Supported by Research Grant CA-05431 from the National Cancer Institute, United States Public Health Service.

** Present address: Section of Neurosurgery, Dept. of Surgery, Univ. of Michigan Medical School, Ann Arbor, Mich., USA. 
carried out at the onset or 1 month after the beginning of administration, produced a $8 / 10$ tumor incidence in two groups of 10 rats each which were fed the dye for 12 months and maintained for an additional 2 months on a dye-free diet. No tumors were obtained in rats receiving the dye under identical dietary conditions but in which partial hepatectomy was not performed.

Guinea pigs have been known to be totally resistant to the hepatocarcinogenic action of amino azo dyes and aromatic amines. The ubiquitous cocarcinogenic action of partial hepatectomy prompted now an attempt to induce liver tumors in this species by combining the administration, at a high level, of $\mathbf{3}^{\prime}$-methyl-DAB (a highly potent hepatic carcinogen in rats at $0.06 \%$ level) with partial hepatectomy. Twenty-eight random-bred male guinea pigs (smooth-haired variety), weighing $380-440 \mathrm{gm}$ at the beginning of the experiment and housed singly per cage, received $0.12 \% 3^{\prime}$-methyl-DAB in an enriched ground chow diet (ARcos et al., 1961); vitamin $C$ was provided by an abundant daily supply of fresh greens. After 1 month 20 animals were partially hepatectomized and 8 animals were "sham" operated. Partial hepatectomy and the "sham" operations were a semiaseptic adaptation of the technique described for rats (HIGGINS and ANDERson, 1931). Anesthesia was produced by $1.5 \%$ Avertin (Winthrop) given subcutaneously (av. $6 \mathrm{ml}$ per animal) and supplementary ether if required. In the partial hepatectomy 50-70\% of the liver tissue was excised; in the "sham" operated controls the liver was exposed and gently massaged but no tissue was removed. After operation the guinea pigs continued to receive the $3^{\prime}$-methyl-DAB-containing diet for an additional 7 months, following which they were sacrificed and autopsied, and the livers examined in minutia. In the partially hepatectomized group total regrowth of liver tissue had occurred. The livers in both groups of guinea pigs were perfectly normal, without any trace of cirrhosis, fatty infiltration or nodularity.

Although the total feeding period of 8 months may appear short in view of the life span of the guinea pig, it should be remembered that in the rat (which species is highly susceptible to the carcinogenic action of the dye) administration of only $0.06 \%$ dietary $3^{\prime}$-methyl-DAB for as little as 2 months brings about $100 \%$ hepatoma incidence without partial hepatectomy in a total observational period of 7 months (Arcos et al., 1960); cirrhosis is already noticeable during the second week in some animals and macroscopically observable tumors begin to emerge at the 7th week. Moreover, the difference in the average life span of the guinea pig (6 years) and of the rat ( 2 years) does not influence the magnitude of the latent period when tumor induction is with an agent toward which both species are susceptible. Thus, with diethylnitrosamine in rats (average initial weight $92 \mathrm{~g}$ ) receiving an average dose of $0.55 \mathrm{mg}$ five times weekly the first tumor appeared at 22 weeks (ARgus and Hoch-LiGET, 1961), whereas in guinea pigs (average initial weight $255 \mathrm{~g}$ ) receiving an average daily dose of $1.78 \mathrm{mg}$ the first tumor appeared at 16 weeks (ARGus and Hoch-Ligetr, 1963). Hence, the presently reported absence of tumor induction in the guinea pig with the combination of high level of $3^{\prime}$-methyl-DAB and partial hepatectomy is apparently not attributable to a too short observational period, and indicates a virtually unimpairable resistance of this species against dietary amino azo dye carcinogenesis. 


\section{Reforences}

Arcos, J. C., Grifhith, G. W., Cunningham, R. W.: Finestructural alterations in cell particles during chemical carcinogenesis II. Further evidence for their involvement in the mechanism of carcinogenesis. The swelling of rat liver mitochondria during feeding of amino azo dyes. J. biophys. biochem. Cytol. 7, 49-60 (1960).

Arcos, J. C. Gosch, H. H., Zickafoose, D.: Fine structural alterations in cell particles during chemical carcinogenesis. III. Selective action of hepatic carcinogens other than 3'-methyl-4-dimethylaminoazobenzene on different types of mitochondrial swelling. Effect of stimulated liver growth. J. biophys. biochem. Cytol. 10, 23-36 (1961).

Argus, M. F., Hoch-LigET, C.: Comparative study of the carcinogenic activity of nitrosamines. J. nat. Cancer Inst. 27, 695-709 (1961); - Induction of malignant tumors in. the guinea pig by oral administration of diethylnitrosamine. J. nat. Cancer Inst. 30, $533-551(1963)$.

Echave Llanos, J. M., SafFe, I. E.: Action stimulatrice de la régénération hépatique sur la croissance des hépatomes spontanés. C. R. Soc. Biol. (Paris) 157, 1807 (1963).

Glinos, A. D., Bucher, N. L. R.: Liver regeneration and carcinogenesis by $p$-dimethylamino azobenzene. Acta Un. int. Cancr. 6, 713-719 (1949).

Guinos, A. D., Bucher, N. L. R., Aur, J. C.: The effect of liver regeneration on tumor formation in rats fed 4-dimethylaminoazobenzene. J. exp. Med. 98, 313-324 (1951).

Higgrns, G. M., Anderson, R. M.: Experimental pathology of the liver. Restoration of the liver in the white rat following partial surgical removal. Arch. Path. 12, 186-202 (1931).

Hollander, C. F., Bentvizzen, P.: Enhancement of urethan induction of hepatomas in mice by prior partial hepatectomy. J. nat. Cancer Inst. 41, 1303-1306 (1968).

LAws, J. O.: Tissue regeneration and tissue development. Brit. J. Cancer 13, 669-674 (1959).

WARWICK, G. P.: The covalent binding of metabolites of tritiated 2-methyl-4-dimethylaminoazobenzene to rat liver nucleic acids and proteins, and the carcinogenicity of the unlabelled compound in partially hepatectomized rats. Europ. J. Cancer 3, 227-233 (1967).

Prof. Dr. Josfer C. Anoos or

Prof. Dr. Mary F. ARGus

Seamen's Memorial Research Laboratory

US Public Health Service Hospital

210 State Street

New Orleans, Louisiana, 70118 (USA) 